\title{
Muscle Creatine Kinase Sequence Elements Regulating Skeletal and Cardiac Muscle Expression in Transgenic Mice
}

\author{
JANE E. JOHNSON, ${ }^{1.2}$ BARBARA J. WOLD, ${ }^{2}$ AND STEPHEN D. HAUSCHKA ${ }^{1 *}$ \\ Biochemistry Department, University of Washington, Seattle, Washington $98195,{ }^{1}$ and Division of Biology, \\ California Institute of Technology, Pasadena, California $91125^{2}$
}

Received 28 November 1988/Accepted 24 April 1989

\begin{abstract}
Muscle creatine kinase (MCK) is expressed at high levels only in skeletal and cardiac muscle tissues. Previous in vitro transfection studies of skeletal muscle myoblasts and fibroblasts had identified two MCK enhancer elements and one proximal promoter element, each of which exhibited expression only in differentiated skeletal muscle. In this study, we have identified several regions of the mouse MCK gene that are responsible for tissue-specific expression in transgenic mice. A fusion gene containing 3,300 nucleotides of MCK $5^{\prime}$ sequence exhibited chloramphenicol acetyltransferase activity levels that were more than $10^{4}$-fold higher in skeletal muscle than in other, nonmuscle tissues such as kidney, liver, and spleen. Expression in cardiac muscle was also greater than in these nonmuscle tissues by 2 to 3 orders of magnitude. Progressive 5' deletions from nucleotide $\mathbf{- 3 3 0 0}$ resulted in reduced expression of the transgene, and one of these resulted in a preferential decrease in expression in cardiac tissue relative to that in skeletal muscle. Of the two enhancer sequences analyzed, only one directed high-level expression in both skeletal and cardiac muscle. The other enhancer activated expression only in skeletal muscle. These data reveal a complex set of cis-acting sequences that have differential effects on MCK expression in skeletal and cardiac muscle.
\end{abstract}

Terminal differentiation in skeletal muscle leads to the activation of many muscle-specific genes, including those encoding myosin heavy and light chains, $\alpha$-actin, troponins I and $T$, tropomyosin, acetylcholine receptor, and creatine kinase (for a review, see reference 4). Some of these genes are expressed in cardiac as well as skeletal muscle, and expression varies significantly during development and maturation of these tissues. A key step in understanding how these differential patterns of expression are established and modulated is identification of cis-acting regulatory sequences in the muscle-specific genes. Much attention has been directed toward identifying such sequence elements by using permanent skeletal myoblast cell lines $(1,2,6,8,19$. $20,22,26,27,31)$. However, relatively little is known about the sequences that govern expression of these genes in cardiac muscle $(10,24,34,36)$.

Muscle creatine kinase (MCK) is expressed at high levels in both skeletal and cardiac muscle of adult animals $(11,21$, 32, 40). Activation of MCK transcription during skeletal myoblast differentiation has been shown $(7,19,29,30,33)$, and multiple cis-acting regulatory sequences have been identified in the $5^{\prime}$ flanking sequence and first intron of the MCK gene $(20,39)$. The best-characterized element is a 207-base-pair (bp) muscle-specific enhancer located about 1,100 nucleotides (nt) $5^{\prime}$ of the MCK transcription start site. Another enhancer element is located within a 900-nt region in the first intron. The proximal 776-nt 5' MCK sequence also displays muscle cell type specificity in cultured cells. but the absolute level of expression from this element is quite low compared with expression when either enhancer is present (20). A myocyte-specific binding activity, MEF1, that interacts with both enhancers but not the proximal element has been identified (5). Furthermore, the intact MEF1 site is required for the $5^{\prime}$ enhancer to function in MCK expression during skeletal myoblast differentiation in culture.

\footnotetext{
* Corresponding author.
}

The ability of these MCK regulatory sequences to function in cardiac muscle expression of the MCK gene has not been studied in cell culture because of the lack of convenient cardiac muscle cell lines. However, recent reports describing the function and tissue distribution of the myogenic determination factors MyoD1 and myogenin raise important questions about the regulatory sequences in those musclespecific genes that are expressed in both skeletal and cardiac muscle $(9,42)$. MyoD1 and myogenin are found only in skeletal muscle, not in cardiac muscle $(9,42)$; interestingly, MyoD1 has been shown to be identical or closely related to the MEF1 MCK-binding activity (J. Buskin, A. B. Lassar, R. L. Davis, H. Weintraub, and S. D. Hauschka, J. Cell Biol. 107:98a, 1988; A. B. Lassar, J. N. Buskin, D. Lockshon, R. L. Davis, S. Apone, S. D. Hauschka, and H. Weintraub, submitted for publication). Do the MCK regulatory sequences identified in skeletal muscle also function in cardiac muscle? To study this question and the function of MCK regulatory sequences in all tissues, we have constructed transgenic mice containing seven different MCKchloramphenicol acetyltransferase (CAT) fusion genes. Here we report expression levels of these genes in skeletal and cardiac muscle as well as in nonmuscle tissues of adult mice. Evidence for regulatory elements with differential effects on MCK expression in skeletal versus cardiac muscle is presented.

\section{MATERIALS AND METHODS}

DNA constructions. Construction of $-3300 \mathrm{MCK}-\mathrm{CAT}$, -1256MCK-CAT, -776MCCK-CAT, -723MCK-CAT. -80MCK-CAT, and p118CAT has been described elsewhere (20). $-117 \mathrm{MCK}-\mathrm{CAT}$ was constructed by blunt-end ligation of the 117-bp Smal fragment from MCK 5 ' flanking sequence into XbaI-cut p118CAT. This resulted in an MCK-CAT junction at $\mathrm{nt}+1$ instead of at $\mathrm{nt}+7$, as in all other MCK-CAT fusion genes. E1-117MCK-CAT was constructed by blunt-end ligation of the SphI-BamHI enhancercontaining fragment from $-1256 \mathrm{MCK}-\mathrm{CAT}$ into the SalI site 


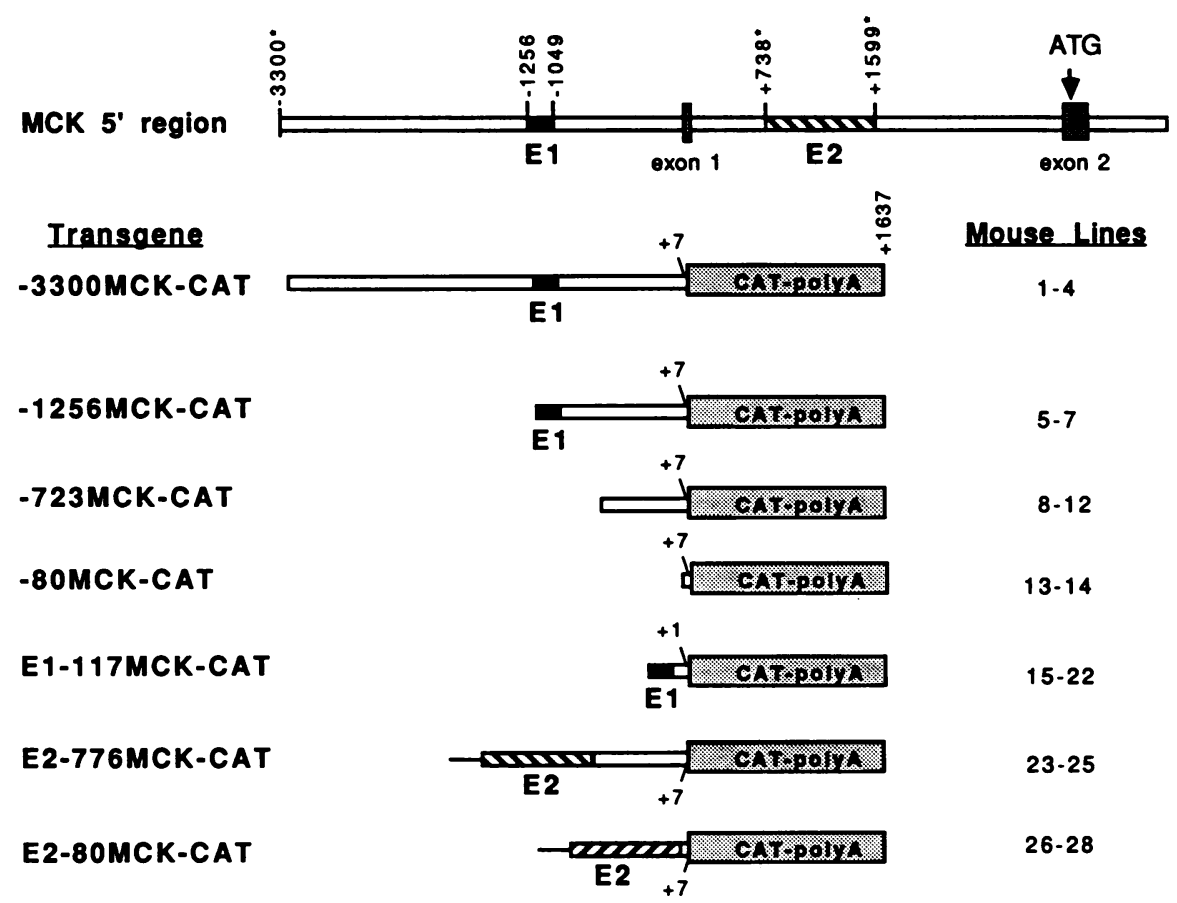

FIG. 1. Maps of MCK-CAT fusion genes. The CAT structural gene-simian virus 40 poly(A) cassette (14) was fused to MCK 5 ' regions at $\mathrm{nt}+7$ in all constructs except E1-117MCK-CAT. in which the fusion was at $\mathrm{nt}+1$. Symbols: enhancer fragment from nt -1256 to -1049 , referred to as E1;,$~ \sim 900$-bp HindIII enhancer fragment from the first intron, referred to as E2: —, approximately 160 bp of pUC118 from the polylinker HindIII to the NarI and $B g / \mathrm{l}$ sites in constructs E2-776MCK-CAT and E2-80MCK-CAT, respectively: *, approximate assignment. In all constructs, the enhancers E1 and E2 are in their proper 5'-to-3' orientations except in E2-80MCK-CAT, in which the E2 enhancer is in the opposite orientation.

of -117MCK-CAT. E2-776MCK-CAT and E2-80MCKCAT were made by ligation of the $\sim 900$-bp HindIII fragment from the first intron of MCK into HindIII-cut $-776 \mathrm{MCK}$ CAT and $-80 \mathrm{MCK}-\mathrm{CAT}$, respectively.

Production of transgenic mice. DNA restriction fragments containing the fusion genes were separated from plasmid vector sequences by agarose (Bethesda Research Laboratories, Inc.) gel electrophoresis. The DNA was purified from the agarose by being dissolved in $8 \mathrm{M}$ sodium perchlorate. bound to GFC paper (Whatman, Inc.), and eluted in $1 \mathrm{mM}$ Tris hydrochloride ( $\mathrm{pH} 7.5)-0.1 \mathrm{mM}$ EDTA. The DNA was diluted to a final concentration of $1.5 \mu \mathrm{g} / \mathrm{ml}$ in $10 \mathrm{mM}$ Tris hydrochloride ( $\mathrm{pH} 7.4)-0.1 \mathrm{mM}$ EDTA.

DNA was injected into one of the pronuclei in $F_{2}$ hybrid eggs (obtained by mating C57BL/6 $\times \mathrm{DBA} / 2$ hybrid adults). Injected eggs were maintained in M16 culture medium (18) overnight in a humidified $37^{\circ} \mathrm{C}$ incubator $\left(5 \% \mathrm{CO}_{2}\right)$. Two-cell embryos were reimplanted into the oviducts of pseudopregnant foster mothers. Positive founder mice were identified by DNA dot blots and, in most cases, outbred to generate heterozygous lines. E2-80MCK-CAT founder mice were sacrificed for analysis and not outbred.

Preparation and analysis of DNA. High-molecular-weight tail DNA was isolated by incubating 1- to 2-cm tail pieces in $1.5 \mathrm{ml}$ of $20 \mathrm{mM}$ Tris hydrochloride $(\mathrm{pH} 7.5)-400 \mathrm{mM}$ $\mathrm{NaCl}-2 \mathrm{mM}$ EDTA-0.5\% sodium dodecyl sulfate-500 $\mu \mathrm{g}$ of proteinase $\mathrm{K}$ for $8 \mathrm{~h}$ at $55^{\circ} \mathrm{C}$. DNA was then phenolchloroform extracted, ethanol precipitated, and suspended in $10 \mathrm{mM}$ Tris hydrochloride $(\mathrm{pH} 7.5)-1 \mathrm{mM}$ EDTA. Initial surveys for the presence of transgenes used DNA dot blots. These were performed by denaturing the tail DNA for $2 \mathrm{~min}$ at $100^{\circ} \mathrm{C}$ in $2 \mathrm{M} \mathrm{NaCl}-0.2 \mathrm{M} \mathrm{NaOH}$ and spotting onto nitrocellulose filters. Filters were hybridized to a ${ }^{32} \mathrm{P}$-labeled
HindIII-BamHI fragment containing the CAT gene (14) at $42^{\circ} \mathrm{C}$ overnight in $50 \%$ formamide $-450 \mathrm{mM} \mathrm{NaCl}-45 \mathrm{mM}$ sodium citrate ( $\mathrm{pH} 7.0$ )- $50 \mathrm{mM} \mathrm{NaH}{ }_{2} \mathrm{PO}_{4}(\mathrm{pH} \mathrm{6.5)-0.1} \mathrm{mg} \mathrm{of}$ herring sperm DNA per ml-10\% dextran sulfate and then washed three times for $30 \mathrm{~min}$ at $50^{\circ} \mathrm{C}$ in $0.5 \%$ sodium dodecyl sulfate-10 $\mathrm{mM}$ Tris hydrochloride ( $\mathrm{pH} 7.8$ )-5 $\mathrm{mM}$ EDTA. DNA samples scoring positive for the presence of CAT sequences in the dot screen were then analyzed by standard DNA gel blots (38) to test for intact genes and to determine the DNA copy number. Most mice containing the transgene were outbred with $(\mathrm{C} 57 \mathrm{BL} / 6 \times \mathrm{DBA} / 2) \mathrm{F}_{1}$ mice. E2-80MCK-CAT founder mice were sacrificed directly for analysis.

Assay for CAT enzyme. Tissue extracts were prepared by Dounce homogenization in $250 \mathrm{mM}$ Tris hydrochloride $\mathrm{pH}$ 7.8)-5 mM EDTA. Homogenates were microcentrifuged at $4^{\circ} \mathrm{C}$ for $10 \mathrm{~min}$; the supernatant was then incubated at $68^{\circ} \mathrm{C}$ for $10 \mathrm{~min}$ and microcentrifuged again at $4^{\circ} \mathrm{C}$ for $10 \mathrm{~min}$, and the final supernatant was stored at $-20^{\circ} \mathrm{C}$. Soluble protein concentrations were determined by Bradford assays (3). Tissue extracts were assayed for CAT activity by incubation for $1 \mathrm{~h}$ at $37^{\circ} \mathrm{C}$ with $\left[{ }^{14} \mathrm{C}\right]$ chloramphenicol $(0.2 \mu \mathrm{Ci} / \mu \mathrm{l} ; 60$ $\mathrm{mCi} / \mathrm{mmol}$; Dupont, NEN Research Products) and $1 \mathrm{mM}$ acetyl coenzyme $A$ in $300 \mathrm{mM}$ Tris hydrochloride ( $\mathrm{pH} \mathrm{7.8).}$ Chromatographic separation and quantitation were performed as previously described (14) except that the scintillant was Ecolite (Westchem). Each assay contained between $0.1 \mathrm{ng}$ and $200 \mu \mathrm{g}$ of protein so that the fraction of chloramphenicol acetylated in the assay was linear with enzyme activity. Total protein in the reaction mix was held constant by using bovine serum albumin. Interference in CAT activity assays has been noted in extracts from some tissues (25). In this work, extracts from all tissues reported were tested for 
TABLE 1. CAT activity in tissues of adult $-3300 \mathrm{MCK}-\mathrm{CAT}$ transgenic mice

\begin{tabular}{lcccc}
\hline \multirow{2}{*}{\multicolumn{1}{c}{ Tissue }} & \multicolumn{4}{c}{ CAT activity (mean $\mu \mathrm{U} / \mathrm{mg}$ of protein \pm SD) } \\
& 1 & \multicolumn{4}{c}{2} & 3 & 4 \\
\cline { 2 - 5 } & 1 & given mouse line & \\
\hline Skeletal muscle & $b \times 10^{5}$ & $6 \times 10^{7} \pm 3 \times 10^{7}$ & $9 \times 10^{7}$ & $2 \times 10^{8}$ \\
Cardiac muscle & $1 \times 10^{4}$ & $8 \times 10^{5} \pm 5 \times 10^{5}$ & $1 \times 10^{6}$ & $1 \times 10^{6}$ \\
Lung & $-{ }^{c}$ & $6 \times 10^{4}$ & $6 \times 10^{4}$ & $2 \times 10^{5}$ \\
Brain & $1 \times 10^{2}$ & $6 \times 10^{4} \pm 4 \times 10^{4}$ & $3 \times 10^{4}$ & $1 \times 10^{5}$ \\
Testis & 30 & $2 \times 10^{4}$ & - & $1 \times 10^{4}$ \\
Uterus & - & $1 \times 10^{4}$ & $1 \times 10^{4}$ & - \\
Blood & - & $6 \times 10^{3}$ & - & - \\
Kidney & 3 & $1 \times 10^{4} \pm 1 \times 10^{4}$ & $2 \times 10^{3}$ & $3 \times 10^{3}$ \\
Liver & 3 & $8 \times 10^{3}$ & $1 \times 10^{3}$ & $3 \times 10^{3}$ \\
Spleen & - & $3 \times 10^{3}$ & $8 \times 10^{2}$ & $6 \times 10^{3}$ \\
\hline
\end{tabular}

" A unit of CAT activity is defined as the amount sufficient to acetylate 1 $\mu \mathrm{mol}$ of chloramphenicol per min (37). Data are from two to eight adult mice. Standard deviations are given only for data averaged from tissues of eight mice. See legend to Fig. 1 for description of the transgene $-3300 \mathrm{MCK}-\mathrm{CAT}$.

Transgenic mouse line 1 contains 3 to 5 copies of the transgene $-3300 \mathrm{MCK}$ CAT; lines 2, 3, and 4 contain 5 to 10 copies.

${ }^{b}$ Superficial gluteus muscle.

c - , Not determined.

interference by mixing experiments. No interference was detected in extracts from leg muscle, brain, lung, or testis. Low-level interference was detected in extracts from spleen $(<140 \mu \mathrm{U} / \mathrm{mg}$ of protein) and from kidney, liver, and heart
$(<20 \mu \mathrm{U} / \mathrm{mg}$ of protein). This degree of interference had no significant effect on the conclusions reported. Enzyme activity was expressed in units as defined by Shaw and Brodsky (37).

\section{RESULTS}

Production of transgenic mice containing MCK-CAT fusion genes. Transgenic mice containing MCK $5^{\prime}$ and intragenic sequences fused to the protein-coding sequence of CAT were generated. Structures of the seven MCK-CAT fusion genes used are shown in Fig. 1. Four of these structures represent a $5^{\prime}$ deletion series containing 3,300, 1,256, 723, and $80 \mathrm{nt}$ of the MCK upstream sequences. The other three constructs contain skeletal muscle-specific enhancers (defined previously by their activity in cultured cells) juxtaposed to various MCK 5' flanking sequences. All constructs were introduced into the mouse germ line by microinjection of MCK-CAT DNA that had been linearized and purified from vector sequences (except for approximately $160 \mathrm{bp}$ of pUC118 on the $5^{\prime}$ end of E2-776MCK-CAT and E2-80MCK-CAT). Southern blots showed that the transgenes were primarily arranged in head-to-tail arrays. The gene copy number in each line was estimated by comparing transgene band intensities with the intensity of an endogenous single-copy gene (J. E. Johnson, Ph.D. thesis, University of Washington, Seattle, 1988). Copy numbers range

TABLE 2. CAT activity in tissues of adult transgenic mice carrying various MCK-CAT fusion genes ${ }^{a}$

\begin{tabular}{|c|c|c|c|c|c|c|}
\hline \multirow{2}{*}{ Transgene } & \multirow{2}{*}{ Line } & \multirow{2}{*}{ Copy no. } & \multirow{2}{*}{$\begin{array}{l}\text { No. of } \\
\text { mice tested }\end{array}$} & \multicolumn{3}{|c|}{ CAT activity (mean $\mu \mathrm{U} / \mathrm{ml}$ of protein $\pm \mathrm{SD}$ ) in ${ }^{h}$ : } \\
\hline & & & & Kidney & Cardiac muscle & Skeletal muscle ${ }^{c}$ \\
\hline \multirow[t]{4}{*}{$-3300 \mathrm{MCK}-\mathrm{CAT}$} & 1 & $3-5$ & 2 & 3 & $1 \times 10^{4}$ & $3 \times 10^{5}$ \\
\hline & 2 & $5-10$ & 8 & $1 \times 10^{4} \pm 1 \times 10^{4}$ & $8 \times 10^{5} \pm 5 \times 10^{5}$ & $6 \times 10^{7} \pm 3 \times 10^{7}$ \\
\hline & 3 & $5-10$ & 2 & $2 \times 10^{3}$ & $1 \times 10^{6}$ & $9 \times 10^{7}$ \\
\hline & 4 & $5-10$ & 2 & $3 \times 10^{3}$ & $1 \times 10^{6}$ & $2 \times 10^{8}$ \\
\hline \multirow[t]{3}{*}{$-1256 \mathrm{MCK}-\mathrm{CAT}$} & 5 & $2-5$ & 2 & 60 & $2 \times 10^{3}$ & $3 \times 10^{5}$ \\
\hline & 6 & $2-5$ & 4 & 10 & $2 \times 10^{2}$ & $6 \times 10^{6}$ \\
\hline & 7 & $2-5$ & 2 & 80 & $3 \times 10^{2}$ & $6 \times 10^{6}$ \\
\hline \multirow[t]{5}{*}{$-723 \mathrm{MCK}-\mathrm{CAT}$} & 8 & $1-3$ & 4 & $<2$ & $<2$ & $<2$ \\
\hline & 9 & $5-10$ & 4 & $<2$ & $<2$ & 20 \\
\hline & 10 & $10-15$ & 3 & $<2$ & 3 & $2 \times 10^{3}$ \\
\hline & 11 & $15-20$ & 7 & $<2$ & 3 & $3 \times 10^{3} \pm 3 \times 10^{3}$ \\
\hline & 12 & $10-15$ & 3 & 10 & 40 & $1 \times 10^{6}$ \\
\hline \multirow[t]{2}{*}{-80MCK-CAT } & $13^{d}$ & $5-10$ & 1 & $<2$ & $<2$ & $<2$ \\
\hline & 14 & $2-5$ & 3 & $<2$ & $<2$ & $<2$ \\
\hline \multirow[t]{8}{*}{ E1-117MCK-CAT } & 15 & 1 & 5 & - & $<2$ & 6 \\
\hline & 16 & $2-5$ & 5 & $<2$ & $<2$ & 60 \\
\hline & 17 & 1 & 3 & $<2$ & $3 \times 10^{2}$ & $8 \times 10^{4}$ \\
\hline & 18 & $1-3$ & 6 & 6 & 30 & $1 \times 10^{5}$ \\
\hline & 19 & $15-20$ & 7 & 3 & $2 \times 10^{3} \pm 1 \times 10^{3}$ & $3 \times 10^{5} \pm 1 \times 10^{5}$ \\
\hline & $20^{d}$ & $10-15$ & 1 & 30 & $6 \times 10^{2}$ & $2 \times 10^{6}$ \\
\hline & 21 & $3-5$ & 3 & 60 & $8 \times 10^{2}$ & $2 \times 10^{6}$ \\
\hline & 22 & $10-15$ & 3 & $2 \times 10^{2}$ & $2 \times 10^{4}$ & $6 \times 10^{6}$ \\
\hline \multirow[t]{3}{*}{ E2-776MCK-CAT } & 23 & $2-5$ & 4 & 20 & 8 & $3 \times 10^{5}$ \\
\hline & 24 & $2-5$ & 2 & 60 & 60 & $2 \times 10^{6}$ \\
\hline & 25 & $5-10$ & 2 & $1 \times 10^{3}$ & $3 \times 10^{2}$ & $6 \times 10^{6}$ \\
\hline \multirow[t]{3}{*}{ E2-80MCK-CAT } & $26^{d}$ & $0.5-2$ & 1 & $<2$ & $<2$ & 25 \\
\hline & $27^{d}$ & $2-5$ & 1 & $<2$ & $<2$ & 30 \\
\hline & $28^{d}$ & $2-5$ & 1 & $<2$ & $<2$ & $8 \times 10^{3}$ \\
\hline
\end{tabular}

\footnotetext{
"See legend to Fig. 1 for description of transgenes.

${ }^{h}$ A unit of CAT activity is defined as the amount sufficient to acetylate $1 \mu$ mol of chloramphenicol per min (37). Standard deviations are given for data averaged from seven or more mice (see Materials and Methods).

"Superficial gluteus muscle.

"Founder mice were sacrificed for analysis and thus may have been mosaic. Data reported are from tissues of the founders. The gene copy number given is a minimum measurement.

$c$ - Not determined.
} 
from 1 to 20 ; estimates for each line are given in Tables 1 and 2.

Expression of -3300MCK-CAT in transgenic mice. The largest segment of MCK tested was 3,300 bp of 5' flanking sequence, which included the site of transcription initiation and $7 \mathrm{nt}$ of $5^{\prime} \mathrm{MCK}$ untranslated leader fused, to a CAT gene cassette (Fig. 1). In multiple independent transgenic lines, the $-3300 \mathrm{MCK}-\mathrm{CAT}$ gene was expressed in a pattern reflecting that observed for endogenous MCK. The level of transgene expression was measured by CAT enzyme activity. Although, as in most other transgene experiments (16, $17,28,41)$, the absolute transgene expression levels varied among different transgenic lines, skeletal muscle reproducibly contained $10^{4}$ - to $10^{5}$-fold more CAT activity than was detected in nonmuscle tissues such as kidney, spleen, and liver (Table 1). Cardiac muscle contained 100-fold less CAT activity than did skeletal muscle, but the level was still 2 to 3 orders of magnitude greater than in most nonmuscle tissues. Brain and lung contained on average 20 -fold more CAT activity than did other nonmuscle tissues. A comparison of CAT and endogenous MCK RNA levels indicated that the CAT activity measured in $-3300 \mathrm{MCK}-\mathrm{CAT}$ transgenic mice was a reasonably accurate reflection of differences in endogenous MCK gene expression among tissues (Johnson, $\mathrm{Ph}$.D. thesis). These experiments also indicated that the correct transcription initiation site was used in the MCKCAT transgenes.

Multiple cis-acting MCK sequences contribute to the transcriptional specificity of MCK-CAT fusion genes in transgenic mice. To test for striated muscle-specific regulatory elements within the 3,300-nt MCK 5' sequence, expression from three MCK-CAT genes containing smaller $5^{\prime}$ regions was analyzed. These had been characterized previously by transient transfection studies, using myogenic cell lines that express muscle-specific genes when switched to growth factor-depleted media $(20 ;$ J. E. Johnson, C. L. Gartside, J. B. Jaynes, and S. D. Hauschka, Dev. Biol., in press). In transgenic mice, the deletions to $\mathrm{nt}-1256,-723$, and -80 resulted in progressive reductions in the level of CAT expression (Fig. 2 and Table 2). The apparent 10-fold or greater difference in expression between $-3300 \mathrm{MCK}-\mathrm{CAT}$ and $-1256 \mathrm{MCK}-\mathrm{CAT}$ was not predicted from cell culture studies, since this deletion had no effect on the level of expression in differentiated skeletal muscle cell cultures. The transgene data suggested the existence of positive cis-acting elements in the MCK 5 ' sequence from -3300 to -1256 . The further decrease in skeletal muscle expression with deletion to $\mathrm{nt}-723$ was anticipated, since these transgenes, with the exception of line 12 , lack the $5^{\prime}$ enhancer element. In mice containing either the $-1256 \mathrm{MCK}-\mathrm{CAT}$ or the $-723 \mathrm{MCK}-\mathrm{CAT}$ construct, expression in nonmuscle tissues such as kidney also decreased 10- to 100-fold (Table 2 ). Thus, the same $10^{4}$ - to $10^{5}$-fold-greater relative expression in skeletal muscle versus kidney persisted in the truncated MCK genes, in contrast to the lack of expression in any tissue of the two lines of transgenic mice containing the $-80 \mathrm{MCK}-\mathrm{CAT}$ fusion gene (Table 2).

Since the $-3300 \mathrm{MCK}-\mathrm{CAT}$ gene was expressed at 30 - to 200-times-higher levels in skeletal than in cardiac muscle, it was of particular interest to determine the behavior of the truncated MCK sequences in cardiac tissue. When $-3300 \mathrm{MCK}-\mathrm{CAT}$ was deleted to either -1256 or -723 , the mean ratio of skeletal to cardiac muscle expression increased by another 100 -fold. Although the expression level in skeletal muscle also decreased when the region from -3300 to $-1256 \mathrm{nt}$ was deleted, the decrease in cardiac
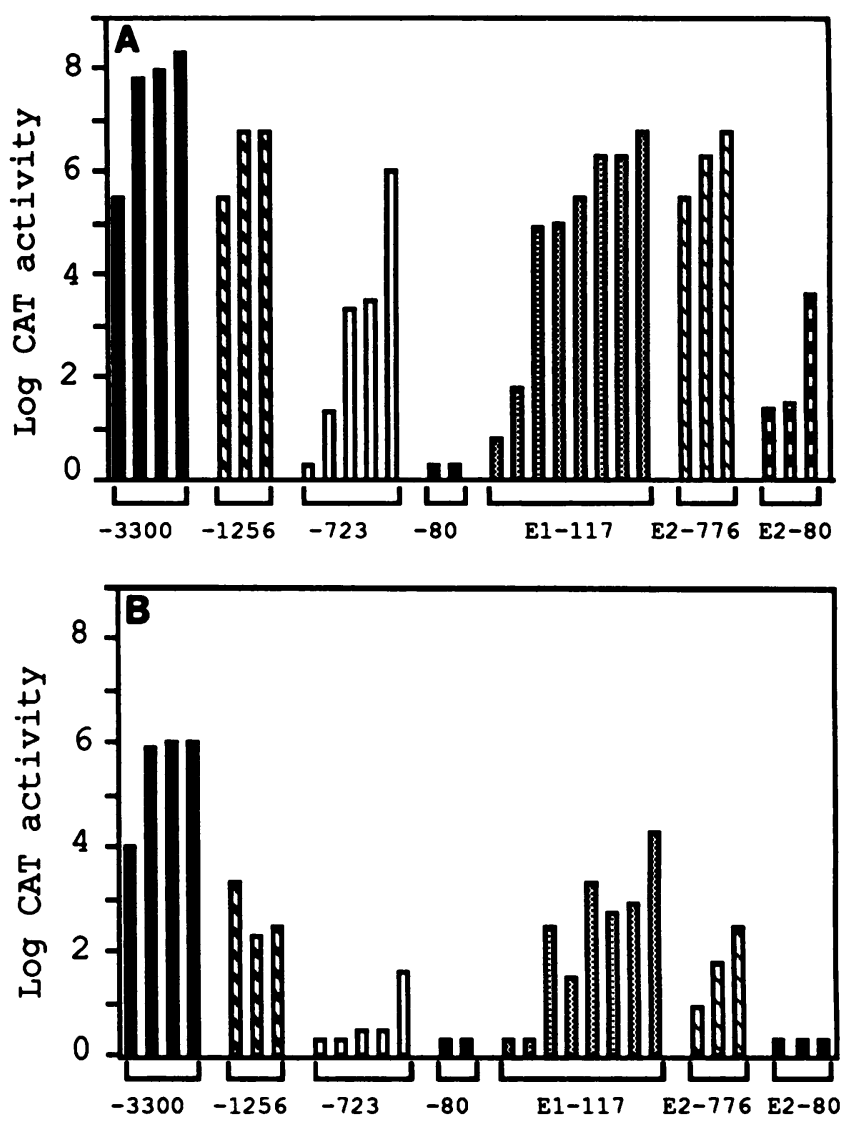

FIG. 2. CAT activity in skeletal (A) and cardiac (B) muscle from MCK-CAT transgenic mice (Table 2). The mouse lines are in consecutive order, beginning with line 1 in each panel. CAT activity is expressed in log units.

muscle expression was greater. Relative to its expression level in kidney, $-723 \mathrm{MCK}-\mathrm{CAT}$ appeared to have minimal, if any, activity in cardiac muscle.

Activation of MCK-CAT fusion genes in muscle by two MCK enhancer elements. Two MCK sequence elements have been identified as skeletal muscle-specific enhancers in cell culture experiments (J. B. Jaynes, Ph.D. thesis, University of Washington, Seattle, 1987; 20, 39). These elements elicit differential effects in skeletal and cardiac muscle of transgenic mice. The $5^{\prime}$ enhancer element, E1, which is normally located between $\mathrm{nt}-1256$ and -1049 , was fused directly to a basal MCK promoter at position -117. (In cell culture transfection studies, the 117-nt MCK 5' sequence exhibits basal-level expression similar to that of $-80 \mathrm{MCK}-\mathrm{CAT}$ and has no skeletal muscle specificity; J. E. Johnson, unpublished results.) The average expression levels of CAT activity in both skeletal and cardiac muscle of E1-117MCK-CAT lines were similar to levels observed for the entire -1256MCK-CAT gene (Fig. 2 and Table 2). Enhancement from the $\mathrm{E} 1$ element was clearly tissue specific. In E1-117MCK-CAT mice, CAT activity in skeletal muscle was $10^{4}$ to $10^{5}$ times greater than in kidney, a ratio similar to that found for mice carrying 3,300,1,256, and $723 \mathrm{nt}$ of MCK $5^{\prime}$ sequence. CAT activity in cardiac muscle was more variable but was still 5 - to $10^{3}$-fold greater than in kidney. This variability may have resulted from greater sensitivity of the regulatory element in cardiac tissue to chromosomal position effects. It is clear, however, that the $5^{\prime}$ enhancer element, in combination with the 117-nt 5' MCK flanking 
region, contains regulatory information for expression in skeletal and cardiac muscle as well as very low level expression in kidney.

The 900-nt intron 1 enhancer element, E2, had a large quantitative effect on transcription when positioned $5^{\prime}$ to the -776 MCK sequence (Fig. 2 and Table 2). All transgenic lines containing E2-776MCK-CAT expressed CAT activity in skeletal muscle at high levels $\left(0.3 \times 10^{6}\right.$ to $6 \times 10^{6} \mu \mathrm{U} / \mathrm{mg}$ of protein) that were about $10^{4}$ times greater than in kidney. When the E2 enhancer was not present on the transgene (as in the $-723 \mathrm{MCK}-\mathrm{CAT}$ construct), only one of five lines expressed such high CAT activity in skeletal muscle (compare E2-776MCK-CAT with -723MCK-CAT in Fig. 2 and Table 2). These data raised the possibility that all of the skeletal muscle specificity observed for the E2-containing construct resides in the -776 segment, with E2 acting only to enhance that expression. Alternatively, E2 might contain muscle specificity of its own that could not be detected above that provided by the -776 element in the E2-776MCK-CAT construct. To distinguish between these possibilities, an E2 construct (E2-80MCK-CAT) containing a basal MCK promoter element with no skeletal muscle specificity was tested. In three independent transgenic founder mice, E2-80MCK-CAT expression was detected only in skeletal muscle (Table 2). These results are consistent with a tissue-specific role for E2 in skeletal muscle expression of MCK. A less plausible but formal possibility is that the $160 \mathrm{nt}$ of vector sequence that is unique to the E2-776MCK-CAT and E2-80MCK-CAT transgenes is responsible for activating expression. Strong positive tissuespecific effects due to vector sequence are, however, unprecedented.

The E2 transgene data are consistent with the possibility that the intron 1 enhancer is nonfunctional in cardiac muscle. In contrast to the expression of E2-776MCK-CAT in skeletal muscle, expression in cardiac muscle was no greater than the low-level expression detected in kidney (Table 2). In addition, no expression of $\mathrm{E} 2$ in conjunction with a basal MCK promoter (E2-80MCK-CAT) was detected in cardiac muscle. These results suggest that E2 may play no role in MCK expression in cardiac muscle, but further dilineation of E2 control elements is necessary before this conclusion becomes firm.

\section{DISCUSSION}

Tissue specificity of MCK gene expression. A 3,300-nt segment of MCK 5' sequence is sufficient to direct high-level expression in a tissue-specific pattern in multiple transgenic lines. $-3300 \mathrm{MCK}-\mathrm{CAT}$ activity in skeletal muscle was $10^{4}$ to $10^{5}$ greater than in nonmuscle tissues such as kidney, liver. and spleen. Expression in cardiac muscle was also high, albeit 10- to 100 -fold less than in skeletal muscle. Although $-3300 \mathrm{MCK}-\mathrm{CAT}$ was expressed at the highest levels in skeletal and cardiac muscle, we also found moderately high levels of CAT activity in brain and lung. This result is consistent with the low levels of endogenous MCK RNA that have been detected in mouse brain and lung (Johnson, Ph.D. thesis) and also with the low levels of the muscle isoform of creatine kinase reported in brains from adult rats (11) and in lungs from adult humans $(12,21)$. Low levels of MCK enzyme activity have also been reported in macrophages, which are present in lung tissue (23), and these cells may be responsible for some or all of the MCK RNA detected in lung tissue as well as for the low levels of CAT enzyme activity detected in tissues such as testes, uterus, kidney, liver, spleen, and blood. In summary, the four tissues expressing the $-3300 \mathrm{MCK}-\mathrm{CAT}$ transgene at the highest levels are those that are known to express the endogenous MCK gene.

Two other murine muscle-specific genes, rat skeletal $\alpha$ actin and myosin light chain 2 , have also been tested in transgenic mice $(10,35,36)$. Transgenes containing twothirds of the rat skeletal muscle actin gene, including $730 \mathrm{bp}$ of $5^{\prime}$ flanking sequence fused to the $3^{\prime}$ end of human embryonic globin, were expressed "exclusively" in skeletal and cardiac muscle. Transgenes containing myosin light chain 2 were expressed only in skeletal muscle. The lower sensitivity of RNA transcript detection relative to CAT enzyme activity may have precluded detection of low-level transgene expression in other tissues.

MCK transcription in skeletal muscle. Deletion of MCK from -3300 to -1256 and to -723 resulted in $10-$ and 100 -fold decreases in the average level of CAT expression in skeletal muscle (Table 2 and Fig. 2). Even though the levels of expression were dramatically reduced by these deletions, muscle specificity remained high $\left(10^{4}\right.$-times-greater activity in skeletal muscle than in kidney) (Table 2). These data are consistent with a model for MCK regulation in which the sequences that regulate muscle specificity reside in the 723-nt segment, with upstream elements providing only quantitative amplification. However, data from mouse lines containing the E1-117MCK-CAT transgene indicate that E1 also confers muscle specificity (Table 2). E2, the intron enhancer, also increased MCK transcription in skeletal muscle (Table 2).

It is interesting to note that while deletion of sequences between -3300 and -1256 had a significant quantitative effect in transgenic animals, the same deletion had no detectable effect in transfected myogenic cells (20; Johnson et al., in press). This may reflect an important difference in the sensitivity of the two systems to regulatory elements between -3300 and -1256 . Alternatively, this deletion may render important internal sequences such as the $E 1$ enhancer more sensitive to negative position effects in transgenic mice.

MCK transcription in cardiac muscle. Introduction of MCK-CAT genes into the mouse germ line permitted an analysis of MCK regulatory elements that affect expression in cardiac muscle. Studies of MCK enzyme activity indicate that adult rodent cardiac muscle contains 10 to 15 times less MCK than does skeletal muscle $(11,15,40)$. A comparable ratio of skeletal to cardiac muscle expression was approached in transgenic experiments only when the full 3,300 nt of MCK 5' sequence was present. When sequences between -3300 and -1256 were deleted, the mean ratio of skeletal to cardiac expression appeared to increase about 200 -fold. A simple explanation for this observation is that one or more distinct cardiac regulatory elements reside between $n t-3300$ and -1256 . Consistent with this possibility, distinct skeletal- versus cardiac-specific regulatory sequences in the chicken troponin $\mathrm{T}$ gene have been identified by using primary cell cultures (24). Although there are other, more complex explanations for the relative loss of cardiac expression, this segment of MCK DNA can now be tested directly for the ability to act on a basal promoter to specify cardiac expression.

Although both MCK enhancers increase transcription in skeletal muscle, the $5^{\prime}$ enhancer but not the intron enhancer also increases transcription in cardiac muscle. The $5^{\prime}$ enhancer is similar to the full $-3,300$-nt sequence in its ability to direct MCK-CAT expression in cardiac muscle relative to 
other tissues (Table 2, see E1-117MCK-CAT). In contrast. the intron enhancer does not activate expression in cardiac muscle over the expression seen in kidney (Table 2, see E2-776MCK-CAT and E2-80MCK-CAT). A possible ambiguity here is that two of the E2-80MCK-CAT mice expressed CAT at such low levels in skeletal muscle that 10to 100-lower levels of expression in cardiac muscle might not have been detectable. Nevertheless, these results, suggesting differences in function of the E1 and E2 enhancers, are reminiscent of those reported for $\alpha$-fetoprotein. In a transient-expression system in hepatoma cells, the three enhancers of $\alpha$-fetoprotein had essentially equivalent and nonadditive activities, but when tested in transgenic mice, the enhancers had different biological effects $(13,16)$. The data for $\alpha$-fetoprotein and MCK suggest that these are examples of genes in which multiple, distinct enhancer elements are responsible for modulation of transcription in a tissuespecific manner during different stages of development and under diverse physiological conditions.

Implications for muscle-specific gene expression. In light of recent data on muscle-specific gene regulation, it is of particular interest that the 207-bp 5' enhancer appears to function in both skeletal and cardiac muscle. A musclespecific binding factor (MEF1), which binds to both the E1 and E2 enhancers, is identical or closely related to MyoD1, a putative myogenic determination factor $(5,9$; Buskin et al., J. Cell Biol. 107:98a, 1988; Lassar et al., submitted). When the MEF1 binding sequence is mutated, E1 loses its ability to enhance MCK expression in differentiating skeletal myoblasts in culture (5). MyoD1, however, is present only in skeletal muscle, not cardiac muscle (9). These data suggest that in cardiac muscle, the MEF1 sequence of $E 1$ is recognized by a MyoD1-related protein or, alternatively, that E1 contains another distinct sequence which functions specifically in cardiac muscle. Studies with transgenic mice containing E1 mutations will distinguish between these two possibilities.

This study has focused on identifying sequence elements in the mouse MCK gene that are quantitatively important in skeletal and cardiac muscle-specific expression in adult animals. It will now be interesting to evaluate the behavior of these constructs at earlier points in development, when the distribution of brain and muscle creatine kinase isoforms is significantly different from that in adult animals $(11,15,43)$.

\section{ACKNOWLEDGMENTS}

We thank Cyndy Gartside, Tom Balestreri, and Dave Clary for excellent technical assistance, Jessie Dausman for training in microinjection and embryo transfer, Tom Wilkie for generating some of the transgenic mice, and Jean Buskin. Paul Mueller, Melvin Simon, and Tom Wilkie for critical reading of the manuscript.

This work was supported by Public Health Service grants AR18860 and HL39070 from the National Institutes of Health and a grant from the Muscular Dystrophy Association to S.D.H.. by Public Health Service grant GM35526 from the National Institutes of Health, by a grant from the Rita Allen Foundation, and by Public Health Service biomedical research grant RR07003 to B.J.W. and training grant HD07183 to J.E.J., both from the National Institutes of Health.

\section{LITERATURE CITED}

1. Bergsma, D. J., J. M. Grichnik, L. M. A. Gossett, and R. J. Schwartz. 1986. Delimitation and characterization of cis-acting DNA sequences required for the regulated expression and transcriptional control of the chicken skeletal $\alpha$-actin gene. Mol. Cell. Biol. 6:2462-2475.

2. Bouvagnet, P. F., E. E. Strehler, G. E. White, M. Strehler-Page,
B. Nadal-Ginard, and V. Mahdavi. 1987. Multiple positive and negative 5 ' regulatory elements control the cell-type-specific expression of the embryonic skeletal myosin heavy-chain gene. Mol. Cell. Biol. 7:4377-4389.

3. Bradford, M. M. 1976. A rapid and sensitive method for the quantitation of microgram quantities of protein utilizing the principle of protein-dye binding. Anal. Biochem. 72:248-254.

4. Buckingham, M. E. 1977. Muscle protein synthesis and its control during the differentiation of skeletal muscle cells in vitro. Int. Rev. Biochem. 15:269-332.

5. Buskin, J. N., and S. D. Hauschka. 1989. Identification of a myocyte nuclear factor that binds to the muscle-specific enhancer of the mouse muscle creatine kinase gene. Mol. Cell. Biol. 9:2627-2640.

6. Carroll, S. L., D. J. Bergsma, and R. J. Schwartz. 1988. A 29-nucleotide DNA segment containing an evolutionarily conserved motif is required in cis for cell-type-restricted repression of the chicken $\alpha$-smooth muscle actin gene core promoter. Mol. Cell. Biol. 8:241-250.

7. Chamberlain, J. S., J. B. Jaynes, and S. D. Hauschka. 1985. Regulation of creatine kinase induction in differentiating mouse myoblasts. Mol. Cell. Biol. 5:484-492.

8. Daubas, P., A. Klarsfeld, I. Garner, C. Pinset, R. Cox, and M. Buckingham. 1988. Functional activity of the two promoters of the myosin alkali light chain gene in primary muscle cell cultures: comparison with other muscle gene promoters and other culture systems. Nucleic Acids Res. 16:1251-1271.

9. Davis, R. L., H. Weintraub, and A. B. Lassar. 1987. Expression of a single transfected cDNA converts fibroblasts to myoblasts. Cell 51:987-1000.

10. Einat, P., Y. Bergman, D. Yaffe, and M. Shani. 1987. Expression in transgenic mice of two genes of different tissue specificity integrated into a single chromosomal site. Genes Dev. 1:10751084.

11. Eppenberger, H. M., M. Eppenberger, R. Richterich, and H. Aebi. 1964. The ontogeny of creatine kinase isozymes. Dev. Biol. 10:1-16.

12. Gazdar, A. F., N. H. Zweig, D. N. Carney, A. C. Van Steirteghin, S. B. Baglin, and J. D. Minna. 1981. Levels of creatine kinase and its BB isozyme in lung cancer specimens. Cancer Res. 41:2773-2777.

13. Godbout, R., R. Ingram, and S. M. Tilghman. 1986. Multiple regulatory elements in the intergenic region between the $\alpha$ fetoprotein and albumin genes. Mol. Cell. Biol. 6:477-487.

14. Gorman, C. M., G. T. Merlino, M. C. Willingham, I. Pastan, and B. H. Howard. 1982. The Rous sarcoma virus long terminal repeat is a strong promoter when introduced into a variety of eukaryotic cells by DNA-mediated transfection. Proc. Natl. Acad. Sci. USA 79:6777-6781.

15. Hall, N., and M. DeLuca. 1975. Developmental changes in creatine phosphokinase isoenzymes in neonatal mouse hearts. Biochem. Biophys. Res. Commun. 66:988-994.

16. Hammer, R. E., R. Krumlauf, S. A. Camper, R. L. Brinster, and S. M. Tilghman. 1987. Diversity of alpha-fetoprotein gene expression in mice generated by a combination of separate enhancer elements. Science 235:53-58.

17. Hammer, R. E., G. H. Swift, D. M. Ornitz, C. J. Quaife, R. D. Palmiter, R. L. Brinster, and R. J. MacDonald. 1987. The rat elastase I regulatory element is an enhancer that directs correct cell-specificity and developmental onset of expression in transgenic mice. Mol. Cell. Biol. 7:2956-2967.

18. Hogan, B., F. Costantini, and E. Lacy. 1986. Manipulating the mouse embryo: a laboratory manual. Cold Spring Harbor Laboratory, Cold Spring Harbor, N.Y.

19. Jaynes, J. B., J. S. Chamberlain, J. N. Buskin, J. E. Johnson, and S. D. Hauschka. 1986. Transcriptional regulation of the muscle creatine kinase gene and regulated expression in transfected mouse myoblasts. Mol. Cell. Biol. 6:2855-2864.

20. Jaynes, J. B., J. E. Johnson, J. N. Buskin, C. L. Gartside, and S. D. Hauschka. 1988. The muscle creatine kinase gene is regulated by multiple upstream elements, including a musclespecific enhancer. Mol. Cell. Biol. 8:62-70.

21. Jockers-Wretou, E., and G. Pfleiderer. 1975. Quantitation of 
creatine kinase isoenzymes in human tissues and sera by an immunological method. Clin. Chim. Acta 58:223-232.

22. Konieczny, S. F., and C. P. Jr. Emerson. 1987. Complex regulation of the muscle-specific contractile protein (troponin I) gene. Mol. Cell. Biol. 7:3065-3075.

23. Loike, J. D., V. F. Kozler, and S. C. Silverstein. 1984. Creatine kinase expression and creatine phosphate accumulation are developmentally regulated during differentiation of mouse and human monocytes. J. Exp. Med. 159:746-757.

24. Mar, J. H., P. B. Antin, T. A. Cooper, and C. P. Ordahl. 1988. Analysis of the upstream regions governing expression of the chicken cardiac troponin $T$ gene in embryonic cardiac and skeletal muscle cells. J. Cell Biol. 107:573-585.

25. Mercola, M., J. Goverman, C. Mirell, and K. Calame. 1985. Immunoglobulin heavy-chain enhancer requires one or more tissue-specific factors. Science 227:266-270.

26. Minty, A., and L. Kedes. 1986. Upstream regions of the human cardiac actin gene that modulate its transcription in muscle cells: presence of an evolutionarily conserved repeated motif. Mol. Cell. Biol. 6:2125-2136.

27. Muscat, G. E. O., and L. Kedes. 1987. Multiple 5 '-flanking regions of the human $\alpha$-skeletal actin gene synergistically modulate muscle-specific expression. Mol. Cell. Biol. 7:4089-4099.

28. Palmiter, D. R., and R. L. Brinster. 1986. Germ-line transformation of mice. Annu. Rev. Genet. 20:465-499.

29. Perriard, J. C. 1979. Developmental regulation of creatine kinase isoenzymes in myogenic cell cultures from chicken. Levels of mRNA for creatine kinase subunits $\mathbf{M}$ and B. J. Biol. Chem. 254:7036-7041.

30. Perriard, J. C., M. Caravatti, E. R. Perriard, and H. M. Eppenberger. 1978. Quantitation of creatine kinase isoenzyme transitions in differentiating chicken embryonic breast muscle and myogenic cell cultures by immunoadsorption. Arch. Biochem. Biophys. 191:90-100.

31. Pieper, F. R., R. L. Slobbe, F. C. S. Ramaekers, H. T. Cuypers, and H. Bloemendal. 1987. Upstream regions of the hamster desmin and vimentin genes regulate expression during in vitro myogenesis. EMBO J. 6:3611-3618.
32. Richterich, R., U. Wiesmann, and B. Cantz. 1967. Comparative studies on creatine kinase and its isoenzymes, p. 243-253. In N. van Thoai and J. Rocher (ed.), Homologous enzymes and biochemical evolution. Gordon and Breach Publishers, New York.

33. Rosenberg, U. B., G. Kunz, A. Frischauf, H. Lehrack, R. Mahr, H. M. Eppenberger, and J. C. Perriard. 1982. Molecular cloning and expression during myogenesis of sequences coding for M-creatine kinase. Proc. Natl. Acad. Sci. USA 79:6589-6592.

34. Rudnicki, M. A., M. Ruben, and M. W. McBurney. 1988. Regulated expression of a transfected human cardiac actin gene during differentiation of multipotential murine embryonal carcinoma cells. Mol. Cell. Biol. 8:406-417.

35. Shani, M. 1985. Tissue-specific expression of rat myosin light chain 2 gene in transgenic mice. Nature (London) 314:283-286.

36. Shani, M. 1986. Tissue-specific and developmentally regulated expression of a chimeric actin/globin gene in transgenic mice. Mol. Cell. Biol. 6:2624-2631.

37. Shaw, W. V., and R. F. Brodsky. 1968. Characterization of chloramphenicol acetyltransferase from chloramphenicol-resistant Staphylococcus aureus. J. Bacteriol. 95:28-36.

38. Southern, E. M. 1975 . Detection of specific sequences among DNA fragments separated by gel electrophoresis. J. Mol. Biol. 98:503-517.

39. Sternberg, E. A., G. Spizz, W. M. Perry, D. Vizard, T. Weil, and E. N. Olson. 1988. Identification of upstream and intragenic regulatory elements that confer cell-type-restricted and differentiation-specific expression on the muscle creatine kinase gene. Mol. Cell. Biol. 8:2896-2909.

40. Tanzer, M. L., and C. Gilvarg. 1959. Creatine and creatine kinase measurement. J. Biol. Chem. 234:3201-3204.

41. Trudel, M., and F. Costantini. 1987. A 3' enhancer contributes to the stage-specific expression of the human $\beta$-globin gene. Genes Dev. 1:954-961.

42. Wright, W. E., D. A. Sassoon, and V. K. Lin. 1989. Myogenin, a factor regulating myogenesis, has a domain homologous to MyoD. Cell 56:607-617.

43. Ziter, F. A. 1974. Creatine kinase in developing skeletal and cardiac muscle of the rat. Exp. Neurol. 43:539-546. 